\title{
The Influence of Diary on the Students' Narrative Writing Skills Quasi-Experimental Study at UIN Syarif Hidayatullah, Jakarta
}

\author{
Ratna Sari Dewi ${ }^{1}$ \\ ${ }^{1}$ Department of English Teacher Education at UIN Jakarta, Indonesia. \\ *Corresponding author: ratna@uinjkt.ac.id
}

\begin{abstract}
This study aims to determine the effect of the diary media on the ability to write narratives for Semester III students. The sample in this study was the 60th semester students of the Department of English Language Education at the Syarif Hidayatullah State Islamic University in Jakarta totalling 60 students. Sampling using a multistage random sampling technique. The method used is an experimental method, with non-equivalent experimental design. Data collection was performed using a narrative writing test and analysed using the t test. The results showed that the diary media had a significant effect on the ability to write student narratives with a coefficient of $t$ count $>$ table $=6.41>1.70$ at a significant level $\alpha=$ 0.05 . These results indicate that the diary media can be used as an alternative media in learning to write student narratives. Therefore, teachers need to know the importance of using appropriate learning media to develop students' narrative writing skills.
\end{abstract}

Keywords: diary media, conventional media, narrative writing ability.

\section{Introduction}

Writing is an activity expressing one's thoughts, ideas and feelings expressed in written language (Guru et al., Nd, Jamila KA Mohamed Kutty et al., 2012, Reese et al., 2010). Looking at the definition, writing is more emphasized on the transfer of information from one's mind or in oral form to written form. Another opinion, states writing is an effort to express what is seen, experienced, felt, and thought into written language (Fenton, 2009). Writing is an expressive activity because the writer is free to express what he feels, both ideas and feelings, such as sad, disappointed, angry, and happy in writing. Based on the description of the theory of the notion of writing above, it can be said that writing is the process of pouring thoughts, ideas, ideas, concepts, and feelings into written form as an attempt to communicate indirectly with others.

Someone who has good writing skills will produce good writing, good writing, namely (1) good writing is interesting; (2) good writing is clear; (3) good writing is concise; (4) good writing is effective; and (5) good writing reflects the writer's original speech (Nguyen \& Gu, 2013, Treiman \& Bourassa, 2000). Writing ability is an important activity to master because this activity cannot be separated from everyone's daily life. This writing ability is important to master because it is productive and expressive which is supported by other language skills, such as listening, speaking, and reading. Writing is productive in producing and processing various knowledge obtained and presented in the appropriate linguistic aspects (Perk, 2015). 
Writing is also expressive because the writer can express his ideas or feelings through the right words so that the reader knows the intent expressed by the writer. (Lasala, 2014, Perk, 2015, Winchester \& Salji, 2016, Kim et al., 2011).

Compared with other language skills, writing skills are the most difficult language skills to master, because writing skills emphasize mastery of various linguistic and nonlinguistic elements in the preparation of a paragraph or writing (Kurniaman et al., 2018, McCardle \& Connelly, 2018). Writing skills also require extensive knowledge and logical mindset (Quinn et al., 2016), Puranik et al., 2018). Extensive knowledge is inseparable from reading activities, so writing activities must be balanced with reading activities (Babayiğit \& Stainthorp, 2010; Fahrurrozi et al., 2019), Wheatley et al., 2016). These activities become obstacles and obstacles for students to carry out writing activities to the full. For this reason, in order for students to realize that everything that works well must go through a process and stages, learning activities must be carried out with the right media and techniques (Foxworth et al., 2017; Zulela et al., 2017). Writing activities must be carried out with routine training, because mastery of writing skills is very beneficial for students to a higher level and can be equipped with social life skills from the community and answer future challenges (Fahrurrozi et al., 2020).

Based on the description above, it can be said that writing skills must be possessed by everyone, especially students, as individuals who involve a lot of writing activities in their daily lives. One of the Competencies of Writing II in the English Education Department that needs attention is the ability to write narration. Narrative writing relates to writing that is narrating events that occur in chronological order (Kurniaman et al., 2018). That is, narration is writing written to convey or tell a person's event or experience chronologically. Narrative can also be referred to as essay which presents the relationship of events by calculating the time element performed by the characters (Listyani, 2019), (Harris et al., 2006). Narrative as a form of discourse can be a form of writing that stands alone, but can also absorb other forms.

In the narrative you can find elements of argumentation, exposition, and description. To get illustrations of narrative forms that have these elements, we can find them in a Roman example or novel (Pérez \& Vargas-Daza, 2019). Narration can be limited as a form of discourse that tells the reader clearly about events that occur. Skillfully writing narration is not easy. Students must be accustomed to expressing events / events into writing. Therefore, the narrative writing process must be familiarized and integrated into the learning process in elementary schools. Several studies Bal, (2019), Foxworth et al., (2017), Balaman, (2018), 
Dinehart, 2015, Ulu, (2019) show that narrative writing skills can be enhanced by media that can motivate someone to write. This is because students must be trained to communicate in writing. That way, students will easily express their ideas through good writing.

The ability to write narratives is certainly important to be mastered by students because it has various benefits that can help students develop their linguistic potential. With the ability to write good narration, students can convey information in a coherent way, both from the order of content, and the time sequence (Juel, 1988, (Klimova, 2014, Kim et al., 2011). This certainly can be applied in the daily lives of students when they want to reveal information so that what they want to convey can be received appropriately and clearly by others. In addition, good mastery of the ability to write narration can also help students in creating a quality story, so that a story made will be more interesting and easier to understand (Teacher et al., $\mathrm{Nd}$, Ismilasari \& Hendratno, 2013).

Seeing the importance of the ability to write narration for students, of course learning to write narration should be closely related to what students do in their daily lives, so that the ability to write narrative students can develop optimally. However, the reality on the ground shows that the ability to write narratives is still low. Based on observations of the third semester students who took Writing II Course, it was found that the ability of students was still low due to several things, namely: 1) students had difficulty in expressing ideas in the form of narrative writing; 2) students are not able to write narratives using the correct spelling and varied vocabulary; 3) the lack of media for narrative writing training in learning to write narration.

In improving narrative writing skills, we need a media that is able to provide motivation in writing. One of them is a diary. A diary is a book that contains experiences, thoughts, and feelings that have been done or experienced by the author on the day concerned (Ningrum \& Rita, 2013, Rausch, 2013). The application of diary media in the process of learning narrative writing can provide opportunities for students to express themselves through writing in expressing their thoughts and feelings about the memorable events that they experienced on the day the diary was written (Dincel \& Savur, 2018). Writing in a diary is a direct reflection of students' involvement in pouring their thoughts into writing because the story written is the student's own experience. In addition, writing in the diary media more refers to the form of narration through the experience or events that are presented coherently based on the time of the incident, there are figures, namely the writer himself, or has a plot, making it easier for students, both to understand the narrative itself, and in practice writing the narration.

Some relevant research Dincel \& Savur, (2018), Can \& Kutluca Canbulat, (2019) states that a diary can have a positive influence on narrative writing skills. In writing a diary, 
of course students will be trained in writing a good story about themselves based on the time sequence they experienced. This is very suitable with the narrative context in which an essay in the form of narrative experience or events that are presented coherently based on the time of the incident (Forgó, 2013, Couzijn, 1999, Canale \& Swain, 1980, Bachman \& Palmer, 1996, Morrow, 2018).

Thus researchers are interested in testing the effect of diaries on narrative writing skills on students at Uin Syarif Hidayatullah, Jakarta.

\section{Materials and Methods}

The method used in this study is an experimental method by using quasi-experimental design. In this study, two groups were given different treatments. The first group was the experimental group that given the treatment of learning using diary. While the second group was the control group that obtains learning by using conventional method. The research design used in this study is nonequivalent control group design.

The population in this study were all third semester students who took writing II course in English education department of UIN Syarif Hidayatullah Jakarta. The target population in this study is all of third semester students in parallel classes who took writing II course.

This study used multistage random sampling technique as a sampling technique of the research. The students from class $\mathrm{C}$ were selected as the experimental class and the students from class A were selected as the control class. Each class consisted of 30 students, so that the total sample was 60 students. The data collection was conducted in 3 months

Next, the instrument used is narrative writing test as the data collection technique in this study. The criteria refers to the conceptual definition of narrative writing skill. The research data analysis technique is done by inferential data analysis. Inferential analysis is divided into two that are test requirements analysis and data analysis. The requirements analysis test is carried out by normality test using Lilliefors test and homogeneity test using Bartlett test, while for inferential analysis the t-test was used.

\section{Results and Discussion}

\section{Data Description}

The data of the research is gained from the score of narrative writing test on the third semester students who took writing II course. In the first meeting, the researcher gives pretest to both classes in order to know students' narrative writing skill from each class. In the 
following meetings, the learning activities were done in eight meeting to both classes, experiment class and control class. After all learning activities are finished, the students were given posttest in both classes with the same instructions as those given during the pretest. Posttest is done with the aim to find out whether there is an influence diary writing on students' narrative writing skill. The results of the pretest and posttest data of the experimental class is presented in the table below:

Table 1. Pretest and Posttest Result of Students' Narrative Writing Skill in Experiment Class

\begin{tabular}{lllc}
\hline & Pretest & \multicolumn{2}{c}{ Experiment Class } \\
\hline $\mathrm{n}$ & 30 & $\mathrm{~N}$ & Posttest \\
Minimum & 16 & Minimum & 30 \\
Maximum & 27 & Maximum & 25 \\
Mean & 22,03 & Mean & 36 \\
Median & 21,5 & Median & 31,47 \\
Mode & 21 & Mode & 32 \\
Standard Deviation & 2,95 & Standard Deviation & 30 \\
Variance & 8,72 & Variance & 3,16 \\
\hline
\end{tabular}

Based on table 1, the maximum score of 30 students in pretest is 27 . While the maximum score in posttest is 36 . The average score if pretest is 22,03 and posttest is 31,47 . The result showed differences after given the treatment. The calculation of pretest and posttest in control class can be seen in the table below:

Table 2. Pretest and Posttest Result of Students' Narrative Writing Skill in Control Class

\begin{tabular}{lrlr} 
& Pretest & Control Class & Posttest \\
\hline $\mathrm{n}$ & & & 30 \\
Minimum & 30 & $\mathrm{n}$ & 20 \\
Maximum & 17 & Minimum & 33 \\
Mean & 26 & Maximum & 25,5 \\
Median & 21,13 & Mean & 25 \\
Mode & 21 & Median & 24 \\
Standard Deviation & 21 & Mode & 3,56 \\
Variance & 2,58 & Standard Deviation & 12,67 \\
\hline
\end{tabular}

Based on table 2, the maximum score of 30 students in pretest from control class is 26. While the maximum score in posttest is 33 . The average score if pretest is 21,13 and posttest is 25,5 . The result showed that the differences are not significant after given conventional media.

Based on posttest data description of the experimental class and the control class that has been described previously, it showed that students' narrative writing in experimental class was higher than the control class. It proven by the average score of the experimental class is 31,47 which is greater than the average score of the control class by 25,5 . 


\section{Testing Data Analysis Requirements}

After gaining the data, the researcher used normality test, homogeneity test, and hypothesis test to analyze statistical data. Normality test is done by using Liliefors test at significance level $\alpha=0,05$. The data are called normal distributed if $\mathrm{L}_{0}\left(\mathrm{~L}_{\text {count }}\right)<\mathrm{L}_{\mathrm{t}}\left(\mathrm{L}_{\text {table }}\right)$.

Table 3 Normality Test of Experiment Class and Control Class

\begin{tabular}{ccc}
\hline Class & Treatment & Lo $_{0}\left(\mathrm{~L}_{\text {count }}\right)$ \\
\hline \multirow{2}{*}{ Experiment } & Pretest & 0,136 \\
& Posttest & 0,100 \\
\multirow{2}{*}{ Control } & Pretest & 0,121 \\
& Posttest & 0,097 \\
\hline
\end{tabular}

The $\mathrm{L}_{\text {table }}$ for 30 samples are 0,161 . Based on the calculation, it gained $\mathrm{L}_{\text {count }}<\mathrm{L}_{\text {table. It }}$ means that the data in experiment class and control class is normally distributed.

Next step is homogeneity test. In this research, the calculation of homogeneity is using Barlett test at significance level $\alpha=0,05$. If $\mathrm{X}_{\text {count }}^{2}<\mathrm{X}^{2}$ table, so the data is called homogeny. Based on the calculation, the value of $X^{2}$ count is 2,78 . While the value of $X_{\text {table }}^{2}$ at significance level 0,05 with dk 3 is 7,81 . Therefore, $X^{2}$ count $<X^{2}$ table $(2,78<7,81)$. It means that the data is homogeneous.

\section{Hypothesis Testing}

Hypothesis testing is carried out in order to determine whether the null hypothesis $\left(\mathrm{H}_{0}\right)$ is rejected or accepted. After finding out that the data gained from both class is normally distributed and homogeny, the researcher continue to carried out hypothesis testing using $t$ test.

Table 4 The Result of Hypothesis Testing

\begin{tabular}{ccccc}
\hline Class & & Average & $\mathbf{t}_{\text {count }}$ & $\mathbf{t}_{\text {table }}$ \\
\hline \multirow{2}{*}{ Experiment } & Pre. & 22,03 & & \\
& Post. & 31,47 & \multirow{2}{*}{6,39} & $1,67 * *$ \\
\multirow{2}{*}{ Control } & Pre. & 21,13 & & \\
& Post. & 25,50 & & \\
\hline
\end{tabular}

Degree of trustworthiness:

* $\quad$ Significance level 0,05

** $\quad$ Significance level 0,05 and 0,01

Based on the calculation, it gained $t_{\text {count }}$ value is 6,39 and $\mathrm{dk}=58$. While $\mathrm{t}_{\text {table }}$ at significance level $\alpha=0,05$ and $\mathrm{dk}=58$ is 2,39 and at the significance level $\alpha=0,01$ and $\mathrm{dk}=58$ is 2,39 . Based on the data above, $\mathrm{t}_{\text {count }}$ is higher than $\mathrm{t}_{\text {table }}(6,39>1,67)$, so null hypothesis $\left(\mathrm{H}_{0}\right)$ is rejected and alternative hypothesis $\left(\mathrm{H}_{1}\right)$ is accepted. It means that the students who taught by using diary 
writing have higher narrative writing skill than the students who are taught with conventional method.

\section{Discussion}

Based on the results of calculations that have been done shows that the score of the ability to write narration of experimental class students, namely the class that uses the diary media is higher than the score of the ability to write narration of control class students, namely the class using conventional media. This is indicated by the posttest average of the experimental class which is higher than the control class, which is $31.47>25.5$. In addition, based on the results of hypothesis testing conducted, it also shows that there is a very significant influence of the diary media on the ability to write narrative students in the experimental class as indicated by $t$ count $>t$ table $(6.39>1.67)$ at a significant level $\alpha=0,05$, and tcount at the significant level $\alpha=0.01$ (6.39> 2.39). This means, $\mathrm{H} 0$ is rejected and $\mathrm{H} 1$ can be accepted which states that students who are taught using diary media have an average test of narrative writing ability that is higher than students who are taught using conventional media.

The results of addressing during the study also showed that writing in a diary made students more easily and interested in writing narratives because what they wrote came from their own experiences. This is also reinforced by the opinion of some experts who revealed that the diary makes someone enjoy the process of making up coral and the results will be a resource in the activity of writing later because it can provide various ideas and inspiration that can break through composing jams, so that through the diary can continue to power creative person (Juel, 1988, Forgó, 2013, Rodríguez-Sosa et al., 2017). By writing in a diary, students become accustomed to expressing their thoughts and feelings in written form, so that the more diligent the students write in their diaries, the more their vocabulary develops.

A diary is a document or personal record of someone who contains experiences, events or events experienced by the author for one day. The diary is written chronologically based on a series of events or events (Dincel \& Savur, 2018). In it can contain personal experiences, be it something that is fun, uplifting, sad, touching, even disappointing. Someone is reluctant to write a diary due to someone's ignorance of what to write, when to write, and why they are writing. The experience of writing a diary can be used as a basis for writing narrative essays because the contents or material of the narrative writing in the form of events or events are the same as the material contained in the diary (Ningrum \& Rita, 2013). In addition, in presenting events or events chronologically is a requirement of both forms of writing. Therefore, 
improving narrative writing skills can utilize diary writing experience (Can \& Kutluca Canbulat, 2019).

In addition, the diary also supports being used as a learning medium in the classroom because it meets the requirements of the learning media selection itself, namely: 1) in accordance with the objectives to be achieved, 2) according to the level of students, 3) the availability of materials, 4 ) procurement costs, and 5) quality / quality (Puranik \& Lonigan, 2014). Thus, the diary is suitable for use in learning to write narration in class because the procurement of the diary itself can use a regular notebook that can act as a diary, so the procurement does not burden any party.

In connection with the above, if students want to be able to write well, the lecturer can give students an understanding of the type of writing into three parts; namely (1) if the writer is writing about himself and his own experience, the goal is self-expression; (2) if writing focuses on the outside world, the author's goal is exposition; and (3) if the main article seeks to influence the reader, the aim is persuasion (Fenton, 2009, Dansky Richard, 2006, Levy, 2009). Self-expression, means that the writer describes personal experiences that occurred in the past or present. The author describes this personal experience with the intention that the reader knows events or events which according to the author are worth knowing by the reader. Exposition, the intention is the author explains something to the reader about an event or event that is not yet known or not fully understood/understood by the reader. Persuasion means that the writer hopes that the reader will be influenced by his writing so that he is interested in participating in the activities carried out by the writer.

Based on the researches Klimova (2014), Winchester \& Salji (2016), Dincel \& Savur, (2018), Duncan et al. (2016) said that the routine of writing a diary conducted by students provides enormous benefits to their abilities in write a narration. In addition, writing this diary is also able to provide opportunities for students to master other aspects of language so that it will continuously make students trained to express ideas and thoughts in good written form. When a student writes a diary, he will indirectly practice to write creatively according to his wishes. In this case, students may choose any topic, for example about himself, his family, friends, his experience, the situation of the village or residence, and other things that are considered interesting to write. The research findings confirms that writing a diary can make students accustomed to expressing their thoughts and feelings in the form of good narratives. In fact, it proves that writing a diary is effective techniques as students taught by this have higher narrative writing skill than the students who are taught with conventional method. 


\section{Conclusion}

Based on the findings and discussion, it is concluded that research hypothesis is accepted. It means that diary writing has significant influence toward narrative writing skill on third semester students of English education department in UIN Syarif Hidayatullah Jakarta. The students who treated with diary writing have more skill in narrative writing than the students who have conventional media. Besides, the result also proven based on the posttest result from both group. The students who treated with diary writing have higher average score in posttest compare with students who have conventional media. Thus, the research revealed that there is significant effect of diary writing ton students narrative writing skill.

\section{References}

Babayiğit, S., \& Stainthorp, R. (2010). Component processes of early reading, spelling, and narrative writing skills in Turkish: a longitudinal study. Reading and Writing, 23(5), 539568. https://doi.org/10.1007/s11145-009-9173-y

Bachman, L. F., \& Palmer, a. S. A. S. (1996). Language Testing in Practice: Designing and Developing Useful Language Tests. In Oxford applied linguistics. https://doi.org/10.2307/328718

Bal, M. (2019). Improving Informative and Narrative Writing Skills Associated with Multimodal Literacy of Middle School Students. World Journal on Educational Technology: Current Issues, 10(4), 250-265. https://doi.org/10.18844/wjet.v10i4.4086

Balaman, S. (2018). Digital storytelling: A multimodal narrative writing genre. Journal of Language and Linguistic Studies, 14(3), 202-212. www.jlls.org

Can, C., \& Kutluca Canbulat, A. N. (2019). Effect of using reflective diaries in teaching turkish on bilingual students' academic achievement and writing skills1. Eurasian Journal of Educational Research, 2019(82), 1-26. https://doi.org/10.14689/ejer.2019.82.1

Canale, M., \& Swain, M. (1980). Theoretical bases of communicative approaches to second language teaching and testing. Applied Linguistics. https://doi.org/10.1093/applin/I.1.1

Couzijn, M. (1999). Learning to write by observation of writing and reading processes: Effects on learning and transfer. Learning and Instruction. https://doi.org/10.1016/S09594752(98)00040-1

Dansky Richard. (2006). Game Writing: Narrative Skills for videogames. Game Writing: Narrative Skills for Videogames.

Dincel, B. K., \& Savur, H. (2018). Diary Keeping in Writing Education. Journal of Education and Training Studies, 7(1), 48. https://doi.org/10.11114/jets.v7i1.3758

Dinehart, L. H. (2015). Handwriting in early childhood education: Current research and future implications. Journal of Early Childhood Literacy, 15(1), 97-118. https://doi.org/10.1177/1468798414522825

Duncan, L. G., Mcgeown, S. P., Griffiths, Y. M., Stothard, S. E., \& Dobai, A. (2016). Adolescent reading skill and engagement with digital and traditional literacies as predictors of reading comprehension. British Journal of Psychology, 107(2), 209-238. 
https://doi.org/10.1111/bjop.12134

Fahrurrozi, Dewi, R. S., Kaban, S., Hasanah, U., Wardhani, P. A., \& Rachmadtullah, R. (2020). Use of Whole Language - Based Initial Reading Asessment Modules in Early Grade Students : Study Efectiveness In Elementary School. International Journal of Advanced Science and Technology, 29(7), 946-953.

Fahrurrozi, Dewi, R. S., \& Rachmadtullah, R. (2019). Experiential Learning Model based on Creative Thinking in Learning to Write Narrative Texts. International Journal of Innovation, Creativity and Change, 5(5), 285-296.

Fenton, N. (2009). Improving your Technical Writing Skills. Writing.

Forgó, S. (2013). New Media, New Media literacy, new methods in education. Proceedings of the 2013 IEEE 63rd Annual Conference International Council for Education Media, ICEM 2013. https://doi.org/10.1109/CICEM.2013.6820148

Foxworth, L. L., Mason, L. H., \& Hughes, C. A. (2017). Improving Narrative Writing Skills of Secondary Students with Disabilities Using Strategy Instruction. Exceptionality, 25(4), 217-234. https://doi.org/10.1080/09362835.2016.1196452

Guru, P., Dasar, S., Negeri, U., Jl, J., \& Jakarta, S. (n.d.). Hubungan penguasaan diksi dan berpikir kreatif dengan kemampuan menulis naratif siswa kelas v sekolah dasar. 124133.

Harris, K. R., Graham, S., \& Mason, L. H. (2006). Improving the writing, knowledge, and motivation of struggling young writers: Effects of self-regulated strategy development with and without peer support. American Educational Research Journal, 43(2), 295-340. https://doi.org/10.3102/00028312043002295

Ismilasari, Y., \& Hendratno. (2013). Penggunaan Media Diorama Untuk Peningkatan Keterampilan Menulis Karangan Narasi Pada Siswa Sekolah Dasar. Yaashinta Ismilasari Hendratno.

Jamila K.A Mohamed Kutty, Mohd Hanafi Mohd Yasin, \& Rosadah Abd. Majid. (2012). Pelaksanaan pengajaran kemahiran membaca dan menulis dalam bahasa melayu bagi murid prasekolah bermasalah pendengaran. Jurnal Pendidikan Bahasa Melayu.

Juel, C. (1988). Learning to Read and Write: A Longitudinal Study of 54 Children From First Through Fourth Grades. Journal of Educational Psychology. https://doi.org/10.1037/0022-0663.80.4.437

Kim, Y. S., Al Otaiba, S., Puranik, C., Folsom, J. S., Greulich, L., \& Wagner, R. K. (2011). Componential skills of beginning writing: An exploratory study. Learning and Individual Differences. https://doi.org/10.1016/j.lindif.2011.06.004

Klimova, B. F. (2014). Approaches to the Teaching of Writing Skills. Procedia - Social and Behavioral Sciences. https://doi.org/10.1016/j.sbspro.2014.01.1149

Kurniaman, O., Yuliani, T., \& Mansur, M. (2018). Investigating Think Talk Write (TTW) Learning Model to Enhance Primary Students' Writing Skill. JOURNAL OF TEACHING AND LEARNING IN ELEMENTARY EDUCATION (JTLEE), 1(1), 52. https://doi.org/10.33578/jtlee.v1i1.5394

Lasala, C. B. (2014). Communicative Competence of Secondary Senior Students: Language Instructional Pocket. Procedia - Social and Behavioral Sciences. https://doi.org/10.1016/j.sbspro.2014.04.243 
Levy, M. (2009). Technologies in use for second language learning. Modern Language Journal. https://doi.org/10.1111/j.1540-4781.2009.00972.x

Listyani. (2019). The use of a visual image to promote narrative writing ability and creativity. Eurasian Journal of Educational Research, 2019(80), 193-224. https://doi.org/10.14689/ejer.2019.80.10

Mccardle, P., \& Connelly, V. (2018). Writing Development in Struggling Learners. Writing Development in Struggling Learners. https://doi.org/10.1163/9789004346369

Morrow, C. K. (2018). Communicative Language Testing. In The TESOL Encyclopedia of English Language Teaching. https://doi.org/10.1002/9781118784235.eelt0383

Nguyen, L. T. C., \& Gu, Y. (2013). Strategy-based instruction: A learner-focused approach to developing learner autonomy. Language Teaching Research. https://doi.org/10.1177/1362168812457528

Ningrum, V., \& Rita, F. (2013). Improving Writing Skill in Writing Recount Text Through Diary Writing. Journal of English Language Teaching Society (ELTS).

Pérez, F. A., \& Vargas-Daza, C. (2019). Shaping Narrative Writing Skills Through Creating Picture Books. GIST - Education and Learning Research Journal, 19(19), 148-171. https://doi.org/10.26817/16925777.700

Perk, M. van der. (2015). A guide for scientific writing. Bachelor Earth Sciences.

Puranik, C. S., \& Lonigan, C. J. (2014). Emergent writing in preschoolers: Preliminary evidence for a theoretical framework. Reading Research Quarterly, 49(4), 453-467. https://doi.org/10.1002/rrq.79

Puranik, C. S., Phillips, B. M., Lonigan, C. J., \& Gibson, E. (2018). Home literacy practices and preschool children's emergent writing skills: An initial investigation. Early Childhood Research Quarterly, 42(May 2016), 228-238. https://doi.org/10.1016/j.ecresq.2017.10.004

Quinn, M. F., Gerde, H. K., \& Bingham, G. E. (2016). Help Me Where I Am: Scaffolding Writing in Preschool Classrooms. Reading Teacher, 70(3), 353-357. https://doi.org/10.1002/trtr.1512

Rausch, A. (2013). Task Characteristics and Learning Potentials-Empirical Results of Three Diary Studies on Workplace Learning. Vocations and Learning. https://doi.org/10.1007/s12186-012-9086-9

Reese, E., Suggate, S., Long, J., \& Schaughency, E. (2010). Children's oral narrative and reading skills in the first 3 years of reading instruction. Reading and Writing. https://doi.org/10.1007/s11145-009-9175-9

Rodríguez-Sosa, J., Lingan, S. K., Hernández, R. M., \& Alhuay-Quispe, J. (2017). Innovation experience in teacher professional development [Experiencia de innovación en desarrollo profesional docente]. Interdisciplinaria.

Treiman, R., \& Bourassa, D. C. (2000). The development of spelling skill. In Topics in Language Disorders. https://doi.org/10.1097/00011363-200020030-00004

Ulu, H. (2019). Investigation of Fourth Grade Primary School Students' Creative Writing and Story Elements in Narrative Text Writing Skills. International Journal of Progressive Education, 15(5), 273-287. https://doi.org/10.29329/ijpe.2019.212.18

Wheatley, B. C., Gerde, H. K., \& Cabell, S. Q. (2016). Integrating Early Writing Into Science 
Instruction in Preschool. Reading Teacher, 70(1), 83-92. https://doi.org/10.1002/trtr.1470

Winchester, C. L., \& Salji, M. (2016). Writing a literature review. Journal of Clinical Urology. https://doi.org/10.1177/2051415816650133

Zulela, M., Siregar, Y. E. Y., Rachmadtullah, R., \& Warhdani, P. A. (2017). Keterampilan Menulis Narasi Melalui Pendekatan Konstruktivisme di Sekolah Dasar. Jurnal Pendidikan Dasar, 8(2), 112-123. 